\section{The Complex Structure of Ferri-ferribactins}

Kambiz Taraz*, Lars Seipold, Cordula Amann and Herbert Budzikiewicz

Institut für Organische Chemie der Universität zu Köln, Greinstr. 4, 50939 Köln, Germany.

Fax:+49-221-470-5057. E-mail: aco88@uni-koeln.de

* Author for correspondence and reprint requests

Z. Naturforsch. 55c, 836-839 (2000);

received June 20, 2000

Pseudomonas chlororaphis, Pseudomonas fluorescens, Ferribactin

By comparison of the NMR data of the ferribactins from Pseudomonas chlororaphis ATCC 9446 and of $P$. fluorescens 18.1 with those of their $\mathrm{Ga}^{3+}$-complexes as models for the $\mathrm{Fe}^{3+}$-complexes it will be shown that only two bidentate ligands are provided for complexation, both located in the peptide chain. The two remainig free sites of the octahedral metal ion are probably occupied by solvent molecules.

\section{Introduction}

Fluorescent members of the rRNA homology group I of the genus Pseudomonas are characterized by the production of so-called pyoverdins, i.e., siderophores consisting of a dihydroxyquinoline chromophore $(\mathbf{1})$ bound amidically to the $\mathrm{N}$ terminus of a peptide chain comprising 6 to 12 amino acids, L as well as D and partially modified (Budzikiewicz, 1997). They are frequently accompanied by ferribactins. Ferribactins have the same peptide chain as the pyoverdins, but the quinoline nucleus is replaced by a condensation product of L-Dab with D-Tyr giving a tetrahydropyrimidine ring. The $\mathrm{NH}_{2}$-group of the Tyr moiety is substituted by the $\gamma$-carboxyl group of L-Glu $(\mathbf{2}, \mathbf{3})$

Abbreviations: Common amino acids, 3-letter code; Dab, 2,4-diaminobutyric acid; Ac/FoOHOrn, $\mathrm{N}^{5}$-acetyl/formyl-N ${ }^{5}$-hydroxy-Orn; cOHOrn, cyclo- $\mathrm{N}^{5}$-hydroxy-Orn (3-amino-1-hydroxy-piperidone-2); DSS, [d 6 -2,2-dimethyl-2-silapentane-5-sulfonate; TMS, tetramethylsilane.

* Part XCIII of the series "Bacterial Constituents". For Part XCII see Amann et al. (2000).

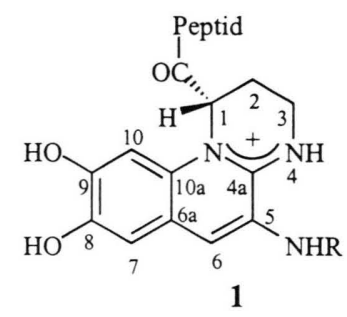

(Taraz et al., 1991). Ferribactins are considered to be the biogenetic precursors of the pyoverdins (Böckmann et al., 1997). They form $\mathrm{Fe}^{3+}$-complexes whose color changes from red at $\mathrm{pH} 3$ to yellow at pH 10 (Budzikiewicz et al., 1992). As in the case of the pyoverdins the peptide chain provides two bidentate ligands. Whether other parts of the ferribactin molecule (e.g., the hydroxyl group of Tyr or the Glu side chain) replace the catecholate unit of the pyoverdins, has been an open question. Clearly, the $\mathrm{Fe}^{3+}$-ferribactin complexes are less stable than the corresponding pyoverdin complexes. The complex constants for the pair from Pseudomonas chlororaphis ATCC 9446 (pyoverdin: $\mathbf{1}$ with the peptide chain of $\mathbf{2}$, ferribactin: 2) (Hohlneicher et al., 1995) assuming a 1:1 stoichiometry for the ferribactin complex are $8.0 \times 10^{25}$ as compared with $3.1 \times 10^{21}$ at $\mathrm{pH} 7.0$ and $1.8 \times 10^{19}$ vs. $5.0 \times 10^{16}$ at pH 5.0 (Hohlneicher, 1993).

\section{Materials and Methods}

Mass spectrometry: Finnigan-MAT 900 ST (ESI). Ferri-2 was dissolved in $\mathrm{CH}_{3} \mathrm{OH} / \mathrm{H}_{2} \mathrm{O}$ / $\mathrm{CH}_{3} \mathrm{COOH}$ 250:250:1 (v/v) $(\mathrm{c}=50 \mathrm{nmol} / \mathrm{ml}, \mathrm{pH}$ ca. 3). For a second measurement the $\mathrm{pH}$ was adjusted to ca 8.5 by addition of a concentrated solution of ammonia. For the complexation experiment $0.1 \mathrm{ml}$ of a solution of 1,10-phenanthroline in $\mathrm{CH}_{3} \mathrm{OH}(\mathrm{c}=600 \mathrm{nmol} / \mathrm{ml})$ were added to $0.4 \mathrm{ml}$ of the original solution.

NMR: DRX $500 \quad\left({ }^{1} \mathrm{H} \quad 500,{ }^{13} \mathrm{C} \quad 125 \mathrm{MHz}\right)$ (Bruker, Karlsruhe). Chemical shifts relative to TMS with the internal standard DSS; $\delta$ (TMS) $=$ $\delta($ DSS $)$ for ${ }^{1} \mathrm{H}, \delta($ DSS $)=-1.61 \mathrm{ppm}$ for ${ }^{13} \mathrm{C}$.

The ferribactins from Pseudomonas chlororaphis ATCC 9446 (2) and from $P$. fluorescens 18.1 (3, peptide chain D-Ser-L-Lys-Gly-FoOH-L- 


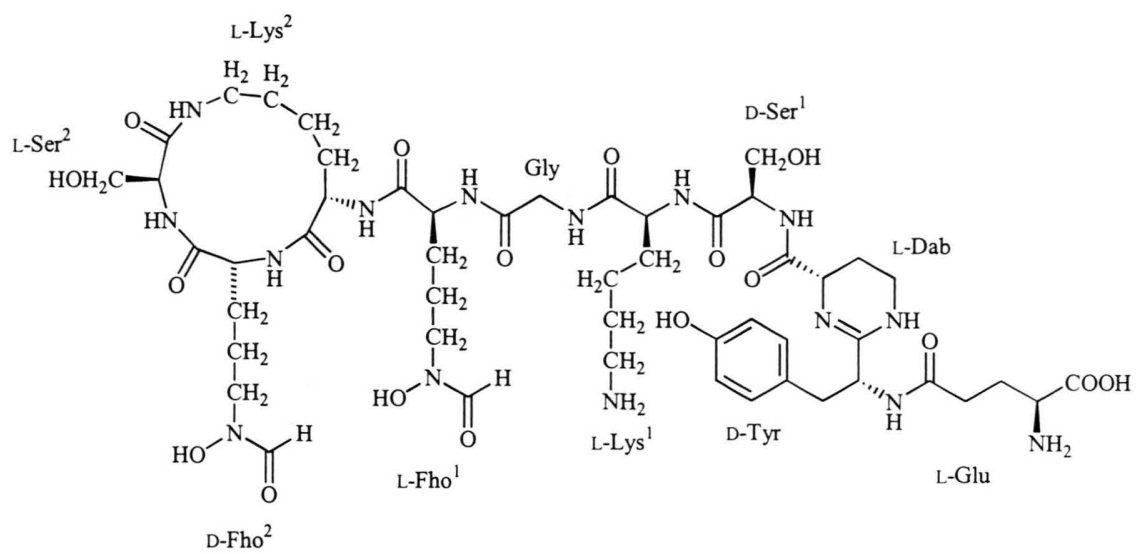

2

Orn-L-Ser-D-Ser-Gly-[L-Lys-L-Ser-FoOH-D-Orn]) were isolated and characterized as described earlier (Hohlneicher et al., 1992; Amann et al., 2000).

While $\mathrm{Ga}^{3+}$-complexes of pyoverdins can readily be purified by chromatography (e.g., Amann et al., 2000), those of ferribactins decompose when a purification is attempted. Even when an excess of $\mathrm{Ga}\left(\mathrm{NO}_{3}\right)_{3}$ is added to a phosphate buffered solution of the ferribactin the complex formation is by far not complete as can be seen from the ${ }^{1} \mathrm{H}-\mathrm{NMR}$ spectra. The phosphate ions seem to compete as complexing agents. For NMR analyses the following procedure proved to be satisfactory: To $15 \mathrm{mg} 2$ dissolved in $3 \mathrm{ml} \mathrm{H}_{2} \mathrm{O} 1.1$ equivalents of $\mathrm{Ga}\left(\mathrm{NO}_{3}\right)_{3}$ dissolved in $1 \mathrm{ml} \mathrm{H}_{2} \mathrm{O}$ were added drop by drop under stirring. A pH of 4.2 was deter- mined potentiometrically after complete addition of the Ga salt. After $1 \mathrm{hr}$ the sample was brought to dryness i.v. $15 \mathrm{mg}$ of $\mathrm{Ga}-2$ were dissolved in $0.9 \mathrm{ml} \mathrm{H}_{2} \mathrm{O}$ and the $\mathrm{pH}$ was adjusted to 4.0 (potentiometric control); $0.1 \mathrm{ml} \mathrm{D}_{2} \mathrm{O}$ were added for the lock signal.

\section{Results and Discussion}

$\mathrm{Ga}^{3+}$-complexes have been used in several instances as models for $\mathrm{Fe}^{3+}$-complexes which are not amenable to NMR spectroscopy, primarily to get information from the ${ }^{1} \mathrm{H}$-data about the threedimensional structures in solution (e.g., Mohn et al., 1994). Both metal ions form octahedral complexes and the ion radius of $\mathrm{Ga}^{3+}(62 \mathrm{pm})$ is very close to that of $\mathrm{Fe}^{3+}(65 \mathrm{pm}) \cdot \mathrm{Ga}^{3+}$ causes changes

Table I. Differences in the ${ }^{13} \mathrm{C}$ chemical shifts $\Delta=\delta($ Ga-ligand $)-\delta$ (ligand).

\begin{tabular}{|c|c|c|c|c|c|c|c|c|}
\hline \multirow[t]{2}{*}{ Pyoverdin } & \multicolumn{5}{|c|}{ Chromophore 1} & \multicolumn{2}{|l|}{ OHOrn } & \multirow[t]{2}{*}{ Lit. } \\
\hline & $\mathrm{C}-7$ & $\mathrm{C}-8$ & C-9 & C-10 & Fo & Ac & cyclo & \\
\hline Pa 27853 & -3.7 & 8.1 & 10.2 & -4.1 & \multirow{5}{*}{$\begin{array}{l}-5.2 \\
-6.1 \\
-6.8\end{array}$} & & -6.7 & 1 \\
\hline Pf $51 \mathrm{~W}$ & -5.1 & 9.2 & 11.0 & -0.5 & & & -4.5 & 2 \\
\hline Pf 18.1 & -3.6 & 7.2 & 9.7 & -3.9 & & & & 3 \\
\hline Pf PL7 & -3.6 & 8.0 & 10.5 & -4.3 & & -10.2 & -6.9 & 4 \\
\hline Pf PL8 & -3.6 & 7.1 & 10.4 & -4.3 & & -10.5 & -7.0 & 4 \\
\hline \multirow[t]{2}{*}{ Ferribactin } & & \multicolumn{3}{|c|}{ Dab/Tyr $(\mathbf{2}, \mathbf{3})$} & & & & \\
\hline & $\mathrm{C}-3$ & C-4 & C-5 & Glu & & & & \\
\hline 2 & 0.1 & 0.0 & 0.1 & 0.1 & -6.1 & & & 5 \\
\hline 3 & -0.1 & 0.0 & -0.1 & 0.2 & -6.3 & & & 5 \\
\hline
\end{tabular}

${ }^{1}$ Tappe (1995); ${ }^{2}$ Amann et al. (2000); ${ }^{3}$ Voss et al. (1999); ${ }^{4}$ Barelmann (1998); ${ }^{5}$ present publication. 
in the electron density at its binding sites resulting in chemical shift differences with reference to the free siderophore. This effect is especially notable for ${ }^{13} \mathrm{C}$-resonances. In the ${ }^{1} \mathrm{H}$-spectra influences due to conformational changes prevail, which bring certain structural units into different shielding or deshielding regions of the molecule. In Table I the shift differences for the binding sites of free pyoverdins and their Ga-complexes are compiled and compared with those of the two ferribactins. Note especially the effect on the C-atoms carrying the $\mathrm{OH}$-groups of the catecholate system $(\mathrm{C}$ 8 and C-9) extending even to the neighboring Catoms.

The shift differences observed for the formyl$\mathrm{CO}$ of the ferribactins $\mathbf{2}$ and $\mathbf{3}$ (-6 ppm) agree with the values observed with pyoverdins. Hence, two ligands are provided by the two FoOHOrn units of $\mathbf{2}$ and 3. Clearly, the hydroxyl group of Tyr does not occupy one of the free complexation sites of $\mathrm{Ga}^{3+}$ : There are no shift differences observed for the 4-hydroxyphenyl ring of Tyr. Another candidate would have been the carboxyl group of the side chain Glu. However, the $\Delta$-values are neglegible. This excludes a participation in the complex formation.

Structures and stoichiometries of dihydroxamate siderophore $\mathrm{Fe}^{3+}$-complexes have been investigated in detail. Essentially two possibilities are under discussion, viz. the formation of 3:2complexes with bridging ligands (e.g., Barclay et al., 1984) and of 1:1-complexes (monomeric or dimeric with the two ligands as bridges) where the free sites of the octahedral metal are occupied by solvent molecules (Caudle et al., 1994b). Equilibria may exist. In acidic media 1:1 complexes seem to prevail.

In the Ga complex of $\mathbf{2}$ several amino acids (Ser, Lys, Tyr and Glu) show doubled signals (shift differences $<0.2 \mathrm{ppm}$ ) which might be interpreted as belonging to ferribactin ligands in a differing arrangement as in a 3:2-complex where two ligands are bound to one $\mathrm{Ga}^{3+}$ each and the third ligand acts as a bridge between the to metal ions. However, different conformations within an 1:1-complex had been observed also for pyoverdins and they resulted in an analogous doubling of signals. In favor of an 1:1-complex are the electrospray ionization mass spectral data. Between ca. $\mathrm{pH} 3$ and $8\left[\mathbf{2}^{56} \mathrm{Fe}^{3+}-2 \mathrm{H}^{+}\right]^{+}\left(\mathrm{m} / z \quad 1231.5\right.$ and $\left[\mathbf{2}+{ }^{56} \mathrm{Fe}^{3+}\right.$ $\left.\mathrm{H}^{+}\right]^{2+}(\mathrm{m} / z$ 616.3) are formed. The isotope pattern of $\mathrm{m} / z, 1231$ shows that it is a singly charged species and not a doubly charged dimer (Caudle et al., 1994b). Solvent molecules occupying the remaining two ligand sites are lost readily in the electrospray process (Caudle et al., 1994a). However, after addition of 1,10-phenanthroline (phen) to the solution of $\mathrm{Fe}^{3+}$-complex of $\mathbf{2}$ the ions $\left[2+{ }^{56} \mathrm{Fe}^{3+}+\text { phen }\right]^{3+}(m / z 471.4)$ and

$\left[2+{ }^{56} \mathrm{Fe}^{3+}+\text { phen }-\mathrm{H}^{+}\right]^{2+}(\mathrm{m} / z$ 706.6) emerged. Phenanthroline is a more strongly bound ligand than $\mathrm{H}_{2} \mathrm{O}$ or $\mathrm{CH}_{3} \mathrm{OH}$. The formation of the 1:1:1-complex confirms the assumption that only four ligand sites of $\mathrm{Fe}^{3+}$ are occupied by the two bidentate FoOHOrn groups of $\mathbf{2}$, the remaining two being free for solvent molecules etc. 
Amann C., Taraz K., Budzikiewicz H. and Meyer J.-M. (2000), The siderophores of Pseudomonas fluorescens 18.1 and the importance of the cyclopeptidic substructures for the recognition at the cell surface. Z. Naturforsch. 55 c, 671-680 (2000).

Barelmann I. (1999), Über die Primär- und Sekundärstrukturen der Pyoverdine aus Pseudomonas fluorescens PL7 und Pseudomonas fluorescens PL8. Dissertation Universität zu Köln.

Barklay S. J., Huynh B. H. and Raymond K. N. (1984), Coordination chemistry of microbial iron transport compounds. 27. Dimeric iron(III) complexes of dihydroxamate analogues of rhodotorulic acid. Inorg. Chem. 23, 2011-2018.

Böckmann M., Taraz K. and Budzikiewicz H. (1997). Biogenesis of the pyoverdin chromophore. Z. Naturforsch. 52c, 319-324.

Budzikiewicz H. (1997), Siderophores from fluorescent Pseudomonas. Studies in Natural Products Chemistry (Atta-ur-Rahman, ed.). Elsevier, Amsterdam; vol. 19, $793-835$.

Budzikiewicz H., Schröder H. and Taraz K. (1992), Zur Biogenese der Pseudomonas-siderophore: Der Nachweis analoger Strukturen eines Pyoverdin-Desferriferribactin-Paares. Z. Naturforsch. 47c, 26-32.

Caudle M. T., Stevens R. D. and Crumbliss A. L. (1994), Electrospray mass spectrometry study of $1: 1$ ferric dihydroxamates. Inorg. Chem. 33, 843-844.

Caudle M. T., Stevens R. D. and Crumbliss A. L. (1994), A monomer-to-dimer shift in a series of 1:1 ferric dihydroxamates probed by electrospray mass spectrometry. Inorg. Chem. 33, 6111-6115.
Hohlneicher U. (1993), Über die Struktur und Biosynthese der Siderophore von Pseudomonas fluorescens ATCC 13525 und Pseudomonas chlororaphis ATCC 9446. Dissertation Universität zu Köln.

Hohlneicher U., Hartmann R., Taraz K. and Budzikiewicz H. (1992), Struktur von Ferribactin aus Pseudomonas fluorescens ATCC 13525. Z. Naturforsch. 47b, 1633-1638.

Hohlneicher U., Hartmann R., Taraz K. and Budzikiewicz H. (1995), Pyoverdin, ferribactin, azotobactin a new triade of siderophores from Pseudomonas chlororaphis and its relation to Pseudomonas fluorescens ATCC 13525. Z. Naturforsch. 50c, 337-344.

Mohn G., Koehl P., Budzikiewicz H.and Lefèvre J.-F. (1994), Solution structure of pyoverdin GM-II. Biochemistry 33, 2843-2851.

Tappe R. (1995), Aufklärung der Primärstruktur eines Pyoverdins von Pseudomonas fluorescens ATCC 27853 und Bestimmung der räumlichen Struktur seines Gallium(III)-Komplexes in Lösung als Modell für den Eisen(III)-Komplex. Dissertation, Universität zu Köln.

Taraz K., Tappe R., Schröder H., Hohlneicher U., Gwose I., Budzikiewicz H., Mohn G. and Lefèvre J.-F. (1991), Ferribactins - the biogenetic precursors of pyoverdins. Z. Naturforsch. 46c, 527-533.

Voss J. A., Taraz K. and Budzikiewicz H. (1999), A pyoverdin from the Antarctica strain $51 \mathrm{~W}$ of Pseudomonas fluorescens. Z. Naturforsch. 54c, 156-162. 